\title{
Team category and gender differences of resilience among high-level volleyball players
}

Categorías de equipos y diferencias de género en cuanto a resiliencia entre los

$$
\text { jugadores de voleibol de alto nivel }
$$

Asterios Patsiaouras ${ }^{1}$

${ }^{1}$ Department of Physical Education \& Sport Science, Karies, Trikala, Greece

Detalles del artículo:

Número de palabras: 3724; Tablas: 2; Figuras: 0; Referencias: 11

Recibido: julio 2020; Aceptado: agosto 2020; Publicado: febrero 2021

Conflicto de interés: El autor declara que no existen conflictos de interés.

Correspondencia del autor: Asterios Patsiaouras, spats@pe.uth.gr

\begin{abstract}
Introduction. The objective of this study was to investigate he difference in resilience level of high-level volleyball players of different team categories. Methods. Ninety-eight volleyball players (50 males and 48 females) of the national team U21, Pre-League and Second Division A2 teams participated in the study and their perceptions were examined using the Self Evaluation Resilience test. Statistical analysis included the use of SPSS 21.0 including t-test for independent samples, and one-way ANOVA with post hoc Bonferroni adjustment test. Results showed statistically significant differences between male and female volleyball players in "orientation on solution and aims", and "self-efficacy" variables and between players of different team categories concerning "orientation on solution and aims", "healthy lifestyle", and "self-efficacy". Future research should investigate whether coaching behavior affects the resilience level of the players in different categories.
\end{abstract}

Key words: sex differences, resilience, High Level Volleyball, self-efficacy, Volleyball National Team.

\section{Resumen}

Introducción. El objetivo de este estudio era investigar la diferencia entre el nivel de resiliencia de los jugadores de voleibol de alto nivel y entre categorías de equipos. Método. En el estudio participaron 98 jugadores de voleibol (jugadores de la selección nacional U21, jugadores de los equipos de Pre-Liga y Segunda División A2) (cincuenta mujeres y cuarenta y ocho hombres). Para el estudio se utilizó la prueba de autoevaluación de resiliencia. Los datos fueron analizados con SPSS 21.0 utilizando la prueba t para muestras independientes y ANOVA de una vía (de sentido único) con la prueba de ajuste de Bonferroni post hoc. Los resultados mostraron diferencias estadísticamente significativas entre los jugadores de voleibol 
masculinos y femeninos en las variables "orientación hacia la solución y los objetivos" y "autoeficacia". Además, se observaron diferencias estadísticamente significativas en las variables "orientación en la solución y objetivos", "estilo de vida saludable" y "autoeficacia" de acuerdo con la categoría del equipo de jugadores. Las búsquedas futuras deberían investigar si el comportamiento del entrenador en el equipo, o la categoría del equipo, afectan al nivel de resiliencia de los jugadores.

Palabras claves: Diferencias de género, resiliencia, voleibol de alto nivel, autoeficacia, equipo nacional de voleibol.

\section{INTRODUCTION}

During the last decade, several researchers attempted to provide an acceptable definition of resilience in sport (Gucciardi, Jackson, Coulter, \& Mallet, 2011; Machida, Irwin, \& Feltz, 2013; Sarkar, \& Fletcher, 2014). Resilience is an individual skill that can be defined as an exertion keeping performance levels relatively stable, and therefore causing positive adaptation in response to exposure to significant perceived difficulties during sport actions (García Secades, Molinero, Salguero, Ruiz, de la Vega, \& Márquez, 2017). Resilience includes two essential factors, that is, response to prolonged exposure to conditions of significant adversity (Gucciardi, Jackson, Coulter, \& Mallet, 2011; Machida, Irwin, \& Feltz, 2013) and the successful positive adaptation to competition levels in various sport settings such as training and games in which each volleyball player must act (Bonanno, 2004; Ruiz, De la Vega, Poveda, Rosado, \& Serpa, 2012).

Gould, Dieffenbach, and Moffett (2002) found that high-level athletes (i.e. Olympic champions winners of 32 Olympic medals) analyzed process and exhibited a greater ability to deal with impediments, stress and adversity than lower-level athletes. Therefore, they suggested that the ability to persevere and overcome setbacks is a key component in helping Olympic champions to reach their goals. Even pessimist and unconfident players can be resilient, however, they may find it more difficult to cope with stressful situations and consequently they may weaken psychologically in case the requirement of the sport such as during volleyball training and games, is too frequent or too persistent. Thus, being optimistic or positive in training and games is always desirable for a volleyball player, but it's not a necessary condition that determines resilience.

Undoubtedly, the outcome of volleyball match is very important for every player, nevertheless, adopting a positive mindset is also important for the process of personal development leading an athlete to feel comfortable with self. García Secades et al. (2017) found that athletes with high resilience attained higher scores in recovery factors and lower scores in stress factors. This is very important since volleyball players with higher resilience levels develop a more positive behavior, having a better and sustained wellbeing and a better performance comparing to volleyball players with low level or resilience (Belem, et al. 2014). 
Although the last decade a plethora of studies has investigated the relation between resilience and sport participation in elite athletes (Gucciardi, Jackson, Coulter, \& Mallet, 2011; Machida, Irwin, \& Feltz, 2013; Sarkar, \& Fletcher, 2014), there is still little evidence on outcome measures specific in volleyball players concerning gender differences. In addition, the recent study of Patsiaouras and Stirbu (2020) highlighted the need to investigate gender differences in volleyball players as authors observed statistically significant differences in resilience between the two genders in volleyball national youth teams (U16).

Thus, further research is needed to examine this issue. Consequently, the purpose of this study was to investigate the resilience of volleyball players and to locate possible differences existing in resilience levels between the two genders and players of different team categories.

\section{MATERIAL AND METHODS}

\section{Participants}

This study involved 98 participants $(\mathrm{M}$ age $=17.38, \mathrm{SD}=2.85), 48$ males $(\mathrm{M}$ age $=16.29$, $\mathrm{SD}=1.57)$ and 50 females $(\mathrm{M}$ age $=18.42, \mathrm{SD}=3.37)$ all volleyball players in different Greek teams, from the Greek National volleyball team of youths (32 males Under 21), Pre-League (18 females), and Volleyball Second Division (A2 category, 16males and 32 females), with several years of experience for both males $(\mathrm{M}$ age $=5.44$ years $)$ and for females ( $\mathrm{M}$ age $=6.94$ years).

\section{Measures}

The Self-Evaluation Resilience test (http://www.resilience-project.eu/index.php$\mathrm{id}=2 \& \mathrm{~L}=10 . \mathrm{html}$ ) was used to measure resilience (Leontopoulou, 2008) that consists of 21 questions with 3 items for each of the seven variables included. The seven variables are: a) "perception" of how someone focus in present making the best for here and now and finds the balance between past- present- and future-oriented thinking (e.g. Q1: I believe that my life is meaningful and worth living), b) "getting a grip of one's life" which refers of how one manages life and finds personal coping strategies to master stress, obstacles and problems while becomes aware of positive aspects (e.g. Q2: I approach things (pleasant and unpleasant) and take action), c) "forming relationships" which refers to resilience and wellbeing as a results of sharing with others (e.g. Q3: I have faith in others and I can rely on their support when I need it), d) "acceptance and optimistic thinking" (confidence in future) skills that foster resilience in daily life (e.g. Q2: I evaluate my experiences and learn from mistakes as well as successes), e) "orientation on solution and aims on getting away from problem thinking and developing thinking skills that enable solutions (e.g. Q3: I have goals for my life and they are consistent with my values), f) "'healthy lifestyle' approach that keeps one physically and mentally healthy to empower personal resilience (e.g. Q3: In a difficult situation, I put my own health before the expectations of others), and g) "self-efficacy" of getting to know personal strengths and the possibility of using own resources in everyday life (e.g. Q3: I believe in myself). 
Answers were provided at a 10-point Likert rating scale (1: total disagree-10: total agree). Information about the reliability of the questionnaire can be located in the study of Patsiaouras and Stirbu (2020) with Cronbach's $\alpha$ ranging from $\alpha=0.62$ for "acceptance and optimistic thinking" to $\alpha=0.87$ for "self-efficacy" respectively. The authors tested youth national team players (18 females and 30 males) from Greek and Romanian National volleyball teams (U16) but they do not provide any information about the validity of the questionnaire e.g. CFI, GFI, RMSEA etc.

\section{Procedures}

Prior to the study, the participants gave their consent for participation and they were assured that the completion of the questionnaires were anonymous and confidential. Participation criteria included that each player should play in high level volleyball teams above Division A2 for at least for two years or be a member of Greek Youth National volleyball team, otherwise the responses of players not meeting the criteria were excluded from further analysis. The participants were contacted directly during their training before March 2020. and completed the questionnaire on the training ground prior or after their training. Completion time of each questionnaire took approximately 10 minutes and following, the questionnaire was placed in a sealed box. The researcher was present during the whole procedure to provide information about the items of the questionnaire that included a series of sentences referring to their current situation that they should answer by circling the number in each item that they think represents them the most. Furthermore, players were assured that there were no right or wrong answers and they that they should not waste a lot of time in each sentence but choose directly what comes to first to their mind. All participants were informed that their participation was voluntary and they were free to withdraw from the research procedure any time they felt so. The study was approved by the Ethical Committee of the University of Thessaly /DPESS.

\section{Statistical Analysis}

Statistical analysis was carried out using SPSS v21.0. Data analysis included descriptive statistics and Cronbach's coefficient alpha to examine internal consistency of each factor. Ttest for independent samples test was also used to examine any differences present between the two genders and one-way ANOVA with Bonferroni correction to test the differences between team categories of players. Furthermore, $\eta^{2} \mathrm{p}$ wad included to determinate the effect size of the results. The alpha level for statistical significance was set at $\mathrm{p}<.05$.

\section{RESULTS}

Reliability analysis using Cronbach's coefficient alpha revealed an internal consistency ranging from moderate-good $(\alpha=0.61)$ to high $(\alpha=0.84)$ for the factors of "acceptance and optimistic thinking (confidence in future) and self-efficacy respectively (Table 1). All items of the test exhibited a high Cronbach's coefficient $\alpha$ score $(\alpha=87)$. The results of t-test for 
independent samples revealed statistically significant differences between the two genders for the "orientation on solution and aims" ( $p=.019)$, and "self-efficacy" ( $p=.047)$ variables, in favor of male volleyball players. No statistically significant differences were observed for the rest resilience test variables between the two genders (Table 1).

Table 1. Independent samples t-test between the two genders (males $\mathrm{N}=48$, females $\mathrm{N}=50$ ) and internal consistency of the variables

\begin{tabular}{|c|c|c|c|c|c|c|c|}
\hline Variable & Gender & Mean & SD & $\mathrm{t}$ & df & $\mathrm{p}$ & Cronbach's $\alpha$ \\
\hline \multirow[t]{2}{*}{ Perception } & males & 24.40 & 2.96 & -.67 & 96 & .947 & 0.62 \\
\hline & females & 24.44 & 3.52 & & & & \\
\hline \multirow[t]{2}{*}{ Getting a grip of one's life } & males & 25.25 & 3.26 & .22 & 96 & .827 & 0.67 \\
\hline & females & 25.10 & 3.50 & & & & \\
\hline \multirow[t]{2}{*}{ Forming relationships } & males & 26.04 & 3.80 & -.68 & 96 & .496 & 0.65 \\
\hline & females & 26.54 & 3.42 & & & & \\
\hline \multirow{2}{*}{$\begin{array}{l}\text { Acceptance and optimistic } \\
\text { thinking (confidence in } \\
\text { future) }\end{array}$} & males & 25.31 & 3.20 & 1.50 & 96 & .135 & 0.61 \\
\hline & females & 24.26 & 3.68 & & & & \\
\hline \multirow{2}{*}{$\begin{array}{l}\text { Orientation on solution } \\
\text { and aims }\end{array}$} & males & 26.38 & 3.46 & 2.12 & 96 & $.019 *$ & 0.71 \\
\hline & females & 24.64 & 4.55 & & & & \\
\hline \multirow[t]{2}{*}{ Healthy lifestyle } & males & 24.85 & 4.85 & -1.32 & 78.74 & .186 & 0.82 \\
\hline & females & 25.94 & 3.06 & & & & \\
\hline \multirow[t]{3}{*}{ Self-efficacy } & males & 27.21 & 3.25 & 1.69 & 96 & $.047 *$ & 0.84 \\
\hline & females & 26.00 & 3.80 & & & & \\
\hline & & & & & & Total & 0.87 \\
\hline
\end{tabular}

$* \mathrm{p}<0.050$

The results of one-way ANOVA test according to the team categories of volleyball players showed statistically significant differences between the groups for "orientation on

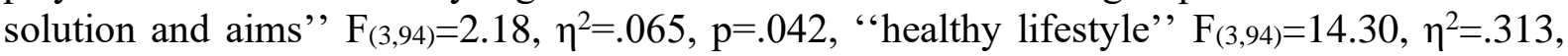
$\mathrm{p}=.000$, and "self-efficacy $\mathrm{F}_{(3,94)}=4.48, \eta^{2}=.125, \mathrm{p}=.006$. No statistically significant differences were observed in other variables between the groups (Table 2).

Bonferroni correction revealed statistically significant differences in a) "orientation on solution and aims" between male National team volleyball players and second Division-A2 female volleyball players ( $\mathrm{I}-\mathrm{J}=2.57, \mathrm{SD}=1.01, \mathrm{p}=.039), \mathrm{b})$ " healthy lifestyle" between male National team volleyball players and male volleyball players of A2 division (I-J=6.63, $\mathrm{SD}=1.05, \mathrm{p}=.000$ ), between Pre- League volleyball and male volleyball players of A2 division $(\mathrm{I}-\mathrm{J}=5.78, \mathrm{SD}=1.17, \mathrm{p}=.000)$, and between female volleyball players of second division and the male volleyball players of second division ( $\mathrm{I}-\mathrm{J}=5.34, \mathrm{SD}=1.04, \mathrm{p}=.000$ ). As a primary result, it seems that the male volleyball players of A2 division paid less attention in healthy lifestyle habits (Table 2). Additionally, Bonferroni correction revealed statistically significant differences in "self-efficacy" between male' National team volleyball players and the PreLeague volleyball players ( $\mathrm{I}-\mathrm{J}=3.42, \mathrm{SD}=1.00, \mathrm{p}=.006)$. 
Table 2. Arithmetic means, standard deviations, ANOVA of resilience variables and Bonferroni 's post hoc test with statistically significant results

\begin{tabular}{|c|c|c|c|c|c|c|c|c|c|c|c|}
\hline Variables & Groups $^{1}$ & M & SD & Groups ${ }^{1}$ & SS & Df & MS & F & $\mathrm{p}$ & $\eta^{2}$ & $\begin{array}{c}\text { Post hoc } \\
\text { test } \\
\text { (Bonferron } \\
\text { i) }\end{array}$ \\
\hline Perception & $\begin{array}{l}\text { a. National Team males } \\
\text { b. Pre-League team } \\
\text { players } \\
\text { c. 2nd Division players } \\
\text { (males) } \\
\text { d. 2nd Division players } \\
\text { (females) }\end{array}$ & $\begin{array}{l}24.66 \\
24.17 \\
23.88 \\
24.59\end{array}$ & $\begin{array}{l}2.85 \\
4.33 \\
3.20 \\
3.03\end{array}$ & $\begin{array}{l}\text { Between } \\
\text { groups } \\
\text { Within } \\
\text { groups } \\
\text { Total }\end{array}$ & $\begin{array}{l}8.66 \\
1009.18 \\
1017.85\end{array}$ & $\begin{array}{l}3 \\
94 \\
97\end{array}$ & $\begin{array}{l}2.89 \\
10.74\end{array}$ & .269 & .848 & .009 & \\
\hline $\begin{array}{l}\text { Getting a grip } \\
\text { of one's life }\end{array}$ & $\begin{array}{l}\text { a. National Team males } \\
\text { b. Pre-League team } \\
\text { players } \\
\text { c. 2nd Division players } \\
\text { (males) } \\
\text { d. 2nd Division players } \\
\text { (females) }\end{array}$ & $\begin{array}{l}25.66 \\
25.00 \\
24.44 \\
25.16\end{array}$ & $\begin{array}{l}2.67 \\
422 \\
4.18 \\
3.10\end{array}$ & $\begin{array}{l}\text { Between } \\
\text { groups } \\
\text { Within } \\
\text { groups } \\
\text { Total }\end{array}$ & $\begin{array}{l}16.68 \\
1083.38 \\
1100.51\end{array}$ & $\begin{array}{l}3 \\
94 \\
97\end{array}$ & $\begin{array}{l}5.60 \\
11.53\end{array}$ & .482 & .695 & .015 & \\
\hline $\begin{array}{l}\text { Forming } \\
\text { relationships }\end{array}$ & $\begin{array}{l}\text { a. National Team males } \\
\text { b. Pre-League team } \\
\text { players } \\
\text { c. 2nd Division players } \\
\text { (males) } \\
\text { d. 2nd Division players } \\
\text { (females) }\end{array}$ & $\begin{array}{l}26.28 \\
25.55 \\
25.56 \\
27.09\end{array}$ & $\begin{array}{l}3.70 \\
4.07 \\
4.08 \\
2.91\end{array}$ & $\begin{array}{l}\text { Between } \\
\text { groups } \\
\text { Within } \\
\text { groups } \\
\text { Total }\end{array}$ & $\begin{array}{l}38.85 \\
1219.57 \\
1258.42\end{array}$ & $\begin{array}{l}3 \\
94 \\
97\end{array}$ & $\begin{array}{l}12.95 \\
12.97\end{array}$ & .998 & .397 & .031 & \\
\hline $\begin{array}{l}\text { Acceptance } \\
\text { and optimistic } \\
\text { thinking } \\
\text { (confidence in } \\
\text { future) }\end{array}$ & $\begin{array}{l}\text { a. National Team males } \\
\text { b. Pre-League team } \\
\text { players } \\
\text { c. 2nd Division players } \\
\text { (males) } \\
\text { d. 2nd Division players } \\
\text { (females) }\end{array}$ & $\begin{array}{l}25.94 \\
24.33 \\
24.06 \\
24.22\end{array}$ & $\begin{array}{l}3.09 \\
4.66 \\
3.13 \\
3.09\end{array}$ & $\begin{array}{l}\text { Between } \\
\text { groups } \\
\text { Within } \\
\text { groups } \\
\text { Total }\end{array}$ & $\begin{array}{l}64.78 \\
1106.28 \\
1171.06\end{array}$ & $\begin{array}{l}3 \\
94 \\
97\end{array}$ & $\begin{array}{l}21.59 \\
11.77\end{array}$ & 1.84 & .146 & .055 & \\
\hline $\begin{array}{l}\text { Orientation on } \\
\text { solution and } \\
\text { aims }\end{array}$ & $\begin{array}{l}\text { a. National Team males } \\
\text { b. Pre-League team } \\
\text { players } \\
\text { c. 2nd Division players } \\
\text { (males) } \\
\text { d. 2nd Division players } \\
\text { (females) }\end{array}$ & $\begin{array}{l}26.88 \\
25.22 \\
25.38 \\
24.31\end{array}$ & $\begin{array}{l}3.09 \\
5.02 \\
4.02 \\
4.31\end{array}$ & $\begin{array}{l}\text { Between } \\
\text { groups } \\
\text { Within } \\
\text { groups } \\
\text { Total }\end{array}$ & $\begin{array}{l}107.25 \\
1541.24 \\
1648.49\end{array}$ & $\begin{array}{l}3 \\
94 \\
97\end{array}$ & $\begin{array}{l}36.75 \\
16.40\end{array}$ & 2.18 & $0.42^{*}$ & .065 & $\begin{array}{l}\mathrm{a}-\mathrm{d} \\
(\mathrm{p}=.039)\end{array}$ \\
\hline $\begin{array}{l}\text { Healthy } \\
\text { lifestyle }\end{array}$ & $\begin{array}{l}\text { a. National Team males } \\
\text { b. Pre-League team } \\
\text { players } \\
\text { c. 2nd Division players } \\
\text { (males) } \\
\text { d. 2nd Division players } \\
\text { (females) }\end{array}$ & $\begin{array}{l}27.06 \\
26.22 \\
20.44 \\
25.78\end{array}$ & $\begin{array}{l}2.69 \\
3.02 \\
5.25 \\
3.12\end{array}$ & $\begin{array}{l}\text { Between } \\
\text { groups } \\
\text { Within } \\
\text { groups } \\
\text { Total }\end{array}$ & $\begin{array}{l}499.28 \\
1094.39 \\
1593.67\end{array}$ & $\begin{array}{l}3 \\
94 \\
97\end{array}$ & $\begin{array}{l}166.43 \\
11.54\end{array}$ & 14.30 & $.000 * * *$ & .313 & $\begin{array}{l}\mathrm{a}-\mathrm{c} \\
(\mathrm{p}=.000) \\
\mathrm{b}-\mathrm{c} \\
(\mathrm{p}=.000) \\
\mathrm{d}-\mathrm{c} \\
(\mathrm{p}=.000)\end{array}$ \\
\hline Self-efficacy & $\begin{array}{l}\text { a. National Team males } \\
\text { b. Pre-League team } \\
\text { players } \\
\text { c. 2nd Division players } \\
\text { (males) } \\
\text { d. 2nd Division players } \\
\text { (females) }\end{array}$ & $\begin{array}{l}28.03 \\
24.61 \\
25.56 \\
26.78\end{array}$ & $\begin{array}{l}2.25 \\
5.25 \\
4.27 \\
2.45\end{array}$ & $\begin{array}{l}\text { Between } \\
\text { groups } \\
\text { Within } \\
\text { groups } \\
\text { Total }\end{array}$ & $\begin{array}{l}155.02 \\
1084.65 \\
1239.67\end{array}$ & $\begin{array}{l}3 \\
94 \\
97\end{array}$ & $\begin{array}{l}51.67 \\
11.54\end{array}$ & 4.48 & $.006^{*}$ & .125 & $\begin{array}{l}\mathrm{a}-\mathrm{b} \\
(\mathrm{p}=.006)\end{array}$ \\
\hline
\end{tabular}

${ }^{1}$ a. Greek Volleyball National Team players U21=32, b. Pre-League Team players $=18$, c. Volleyball Team players second Division-A2 (males=16), d. Volleyball Team players second Division-A2 (females =32)

*Significant at 050 level

$* * *$ Significant at .001 level

\section{DISCUSSION}

The purpose of the study was to assess probable differences of resilience levels between male and female volleyball players and players participating in different volleyball categories.

Using the self-evaluation resilience test, no statistically significant difference observed between the two genders for "perception", "getting a grip of one's life", "forming relationships", and "acceptance and optimistic thinking"' variables. Findings show that both genders are in position to manage equally their life, to find own coping strategies to master 
stress situations, overcome obstacles and related problems occurred and become aware of positive aspects of volleyball sport. Furthermore, both genders can focus in present, making the best for 'here and now' and find the balance between past- present- and future-oriented thinking. Furthermore, both genders perceive that they achieve physical vitality, social satisfaction, a sense of accomplishment, and a personal fulfillment as a result of participating and sharing with others within the volleyball team and foster resilience in daily life. These finding are in agreement with the recent study of Patsiaouras and Stirbu (2020) that did not trace any gender differences for the above-mentioned variables.

The differences observed between national team players comparing to those from A2 Division players concerning "orientation on solution and aims" which refers on getting away from problem thinking and developing thinking skills that enable solutions, suggest that high level volleyball players are more concentrated on finding solutions comparing to low level volleyball players. These findings are in line with García Secades, et al. (2016) and Garcia Secades, et al. (2017) which suggested that high resilience athletes may have developed strategies to help them cope with demanding situations and early withdrawal strategies to avoid unpleasant emotions that, in turn, results to remain focus and continue their activities unaffected in the future. Nevertheless, trivial $\eta 2$ effect size $\left(\eta^{2}=.065\right)$ results also suggest that these differences should be viewed as applied only to the specific group without generalizing the results, a finding that constitutes a limitation of this study.

Statistically significant results in "'healthy lifestyle"' approach that keeps one physically and mentally healthy and empowers resilience that is observed between male National team volleyball players and male volleyball players of A2 division, Pre- League volleyball and male volleyball players of $\mathrm{A} 2$ division and between female volleyball players of second division and the male volleyball players of second division ( $\mathrm{I}-\mathrm{J}=5.34, \mathrm{SD}=1.04, \mathrm{p}=.000)$, suggest that high level volleyball players are focus more on their healthy lifestyle perceived as more important variable that helps them play volleyball comparing to low level volleyball athletes such as players from second Division-A2. This is an interesting finding since Patsiaouras and Stirbu (2020) study also noted differences between the two genders regarding this variable. Thus, a "healthy lifestyle" may not be affected only by gender but also the category of the participating team that additionally affects the resilience level of a volleyball player. Furthermore, the $\eta 2$ effect size test reported as medium $\left(\eta^{2}=. .313\right)$ results shows that these differences should further be investigated in the future.

As for "self-efficacy" differences observed in favor of male National team players compared to Pre-League volleyball players, findings suggest that high-level volleyball players may know better their own strengths and develop more effective strategies to use own resources in everyday life. Additionally, small $\eta 2$ effect size and effect $\left(\eta^{2}=.125\right)$ suggest further future investigation. Data suggested that "self-efficacy" may be affected not only by gender as Patsiaouras and Stirbu (2020) highlighted, but also by the category of a team a volleyball player participates. 


\section{CONCLUSIONS}

The results of this study showed that volleyball coaches should focus more on gender differences in resilience level without, however, overlooking the team category of the players.

The female volleyball players are more oriented to healthy life style and exhibited a lower determination to overcome obstacles that would interfere in volleyball so as to achieve their self-efficacy goals comparing to males' volleyball players. Furthermore, it appears that it was easier for male volleyball players to get away from problem thinking and develop thinking skills that enable solutions compared to female volleyball players.

Finally, volleyball coaches should take into account team category as well, since high level volleyball players can concentrate more on finding solutions, adopt a healthier life style and overcome problems compared to low level volleyball players. Thus, practicing these elements can help the volleyball coach to increase the players' resilience level and, in this way, to additionally optimize the technical and tactical capacity of the team.

\section{LIMITATIONS OF THE STUDY}

The participants and sample size that included only volleyball players along with the relatively small number of studies investigating resilience in volleyball were the major limitations of the present study. Further research should investigate whether additional aspects like the behavior of the coach in the team, or the team category affects the resilience level of the players as well as the processes and the strategies that high-level resilience volleyball players develop as compared to low-level resilience volleyball players.

Although the findings should be interpreted with caution, this study has several strengths. One of the strengths of this study is that represents a comprehensive examination of the resilience level among high level volleyball players. The study provides an in-depth view of the topic of resilience and the differences between gender and team category in volleyball sport and can be generalized in volleyball teams. Another strength of the present study is that the data can relatively easily analyzed by the coaches who might want to evaluate the resilience level of their volleyball players. 


\section{REFERENCES}

Belem, I. C., Caruzzo, N. M., Nascimento Junior, J.R.A.D., Vieira, J.L.L., Vieira, L.F. (2014). Impact of coping strategies on resilience of elite beach volleyball athletes, Revista Brasileira de Cineantropometria \& Desempenho Humano, 16(4) 447-455. https://doi.org/10.5007/1980-0037.2014v16n4p447

Bonanno, G. A. (2004). Loss, trauma and human resilience: Have we underestimated the human capacity to thrive after extremely aversive events? American Psychologist, 59(1), 20-28.

García Secades, X., Molinero, O., Ruíz Barquín, R., Salguero, A., De La Vega, R., Márquez, S. (2017). Resilience and recovery-stress in competitive athletes. Cuadernos de Psicología del Deporte, 17 (2), 73-80.

Gould, D., Dieffenbach, K., Moffett, A. (2002). Psychological characteristics and their development in Olympic champions. Journal of Applied Sport Psychology, 14(3), 172-204.

Gucciardi, D. F., Jackson, B., Coulter, T. J., Mallett, C. J. (2011). The Connor-Davidson Resilience Scale (CDRISC): Dimensionality and age-related measurement invariance with Australian cricketers. Psychology of Sport and Exercise, 12(4), 423-433.

Leontopoulou, S. (2008). A cross - cultural study of resilience in young people. In P. Roussi, E., Vassilaki, \& K. Kaniasty, (Eds.), Stress and psychosocial resources: Coping with life changes, occupational demands, educational challenges, and threats to physical and emotional well-being (pp. 31-44). Berlin: Logos Verlag.

Machida, M., Irwin, B., Feltz, D. (2013). Resilience in competitive athletes with spinal cord injury: the role of sport participation. Qualitative Health Research, 23(8), 1054-1065.

Patsiaouras, A., Stirbu, C. (2020). Assessing Resilience in Youth (U16) Volleyball National Teams. International Journal of Physical Education, Fitness and Sports, 9(3), 39-45. https://doi.org/10.34256/ijpefs2036

Ruiz, R., de la Vega, R., Poveda, J., Rosado, A., Serpa, S. (2012). Análisis psicométrico de la Escala de Resiliencia en el deporte del fútbol. Revista de Psicología del Deporte, 21(1), 143-151.

Sarkar, M., Fletcher, D. (2014). Psychological resilience in sport performers: a review of stressors and protective factors. Journal of Sports Sciences, 32(15), 1419-1434. https://doi.org/10.1080/02640414.2014.901551

García Secades, X., Molinero, O., Salguero, A., Ruíz Barquín, R., de la Vega, R., Márquez, S. (2016). Relationship Between Resilience and Coping Strategies in Competitive Sport. Perceptual and Motor Skills 2016, Vol. 122(1) 336-349. https://doi.org/10.1177/0031512516631056 